\title{
PHYSIOLOGICAL STUDIES ON JERUSALEM ARTICHOKE 1- PRODUCTIVITY AND QUALITY OF JERUSALEM ARTICHOKE IN THE NEW RECLAIMED LANDS. \\ Alian, Fatma S. ${ }^{*}$ and Manal M. Attia** \\ * Potato and vegetatively propagated crops Dept., Horticulture Res. Inst., Agric. Res. Center, Giza, Egypt. \\ ${ }^{* *}$ Postharvest and Handling of Vegetable Crops Dept. Horticulture Res. Inst., Agric. Res. Center, Giza, Egypt.
}

\begin{abstract}
A field experiment was carried out in sandy soil in EL-Kattba, Manofya Governorate Egypt, during the successive growing seasons of 2007 and 2008 on Jerusalem artichoke. The main objective of this investigation was to study the effect of cultivars (Local and Fusaeu $)$ and two planting dates $\left(15^{\text {th }}\right.$ April and $15^{\text {th }}$ May $)$ with two harvesting dates $\left(15^{\text {th }}\right.$ Nov. and $15^{\text {th }}$ Dec.) on vegetative growth, total yield, marketable yield and its components of Jerusalem artichoke. The results indicated that Local cultivar showed higher foliage (plant height) than Fusaeu, but there was no significant effect on number of lateral branches / plant .In addition, Local cultivar showed significant increases in total yield and its components and tuber contents of dry matter, inulin and total sugar compared with Fusaeu .

Concerning planting dates, results showed that the planting on $15^{\text {th }}$ of April increased significantly the vegetative growth parameters, total yield and its components, and tuber contents of dry matter, inulin and total sugar in comparison with planting on $15^{\text {th }}$ May. Regarding the harvest date, data revealed a positive effect of tubers harvest on $15^{\text {th }}$ of Nov. on total yield and its components, and tuber contents of dry matter, inulin while total sugar decreased compared with tubers harvest on $15^{\text {th }}$ Dec.

The interactions between cultivars and planting dates showed that Local cultivar and planting on $15^{\text {th }}$ of April increased significantly the vegetative growth, total yield and chemical constituents of tubers under sandy soil conditions. Also, Local cultivar tubers harvested on $15^{\text {th }}$ of Nov. produced higher significant total yield and its components, and tuber contents of dry matter, inulin while total sugar decreased compared with tubers harvested on $15^{\text {th }}$ of May. The interactions among cultivars, planting dates with harvesting dates, showed that the Local cultivar planted on $15^{\text {th }}$ of April and harvested tubers on $15^{\text {th }}$ of Nov. produced higher significant increases in yield parameters and chemical constituents of tubers under sandy soil conditions.

Finally, it could be concluded that the optimum planting dates of Jerusalem artichoke (Local cultivar) was on $15^{\text {th }}$ of April and the ideal harvesting date was on $15^{\text {th }}$ of Nov. for a highly production and quality of tubers under sandy soil.
\end{abstract}

\section{INTRODUCTION}

Jerusalem artichoke (Helianthus tuberosus L.) is an agricultural crop with a great potential for high sugar yields per he $e^{-1}(9-3 \mathrm{t} / \mathrm{ha}$, Klaushofer, 1986). This crop is known as tuberous crop, which is recently introduced to Egypt for its high nutritional and medicinal values. In France, it has been considered as a source of fructose sugar and fuel alcohol in inulin production. It is most favored as a food in Europe and China (Galindo and 
Guiraud, 1997). Tubers are rich in nutrients and polysaccharides especially inulin which possible utilization as a fructose sweetener (Chubey and Dorrel, 1974). Jerusalem artichoke is one of the most important candidates for use as a raw material for the industrial production of biological fructose and inulin. It is a particularly interesting and suitable crop, for southern European countries and especially in low-requirement environments (Paolini et al., 1996; D'egidio et al., 1998). Furthermore, the crop produced large haulm that can be used as green fodder or silage. The total yield of tubers and quality were affected by cultivars and new clones of Jerusalem artichoke. This result was recorded by Galindinio and Guiraud (1997), Tawfik et al, (2003), and Balidini ( 2004) .Planting and harvesting dates play an important role for high tuber yield production (Leible,1988).Similar results were obtained by (Soja et al., 1990, and Galindinio and Guiraud( 1997). The aim of this study was to compare the planting dates, harvest dates and cultivars under sandy soil conditions on growth, yield and chemical constituents of Jerusalem artichoke.

\section{MATERIALS AND METHODES}

The field experiment was carried out during two successive summer growing seasons of 2007 and 2008 at EL-Katatba in sandy soil and drip irrigation system. Two cultivars (Fusaeu and Local) and two planting dates ( $15^{\text {th }}$ of April and $15^{\text {th }}$ of May) were tested .The experimental design used was split plot with three replicates. The cultivars were in the main plots and the planting dates were in the sub plots. The harvest dates $\left(15^{\text {th }}\right.$ of November, and $15^{\text {th }}$ of December) were in sub-sub plot. The tubers were planted in rows $20 \mathrm{~m}$ length and one meter in width and the distance between tubers were 50 $\mathrm{cm}$. The area of the experimental unit was $20 \mathrm{~m}^{2}$ and consisted of one row. All treatments received an identical amount of composted farmyard manure at a rate of $20 \mathrm{~m}^{3} / \mathrm{fed}$. and mineral fertilizers. Three plants were taken randomly from each treatment at 90 days after planting (beginning of the blooming stage) to determine the stem length, and number of main lateral branches/plant. At harvest time, total yield, marketable yield per fed ${ }^{-1}$, total tuber yield per plant and fresh weight of tuber were recorded as well as dry matter of tuber (calculated by drying 100 grams of fresh tuber in an oven at $70^{\circ} \mathrm{C}$ till a constant weight) (A.O.A.C ,1990).

Inulin percentage of tubers was determined according to Winton and Winton (1958) and total sugar percentage in tubers according to Nelson (1974) and Somogi (1952). Data were statistically analyzed by using a General Liner Model procedure of SAS Institute (1989). Fishers protected least significant (LSD) at $\mathrm{P}<0.05$ was employed to separate the treatment means.

\section{RESULTS AND DISCUSSION}

\section{Vegetative growth}

Local cultivar showed significant increment in plant height and number of lateral branches compared with Fusaeu cultivar (Table 1). However the 
difference in number of branches between two cultivars was not significant in the second season. Similar, findings among Jerusalem artichoke cultivars and clones had been previously reported by Khereba (1979) and Spitters (1987).

Table (1): Effect of cultivars and planting dates on vegetative growth on Jerusalem artichoke plants in 2007 and 2008 seasons.

\begin{tabular}{|c|c|c|c|c|}
\hline \multirow[b]{2}{*}{ Treatment } & \multicolumn{2}{|c|}{ Plant height (cm) } & \multicolumn{2}{|c|}{ No. of lateral stems/plant } \\
\hline & 2007 & 2008 & 2007 & 2008 \\
\hline \multicolumn{5}{|c|}{ Cultivars (C.V) } \\
\hline Fuaesu & 189.98 & 208.4 & 6.84 & 10.35 \\
\hline Local & 202.06 & 214.7 & 7.22 & 10.53 \\
\hline \multicolumn{5}{|c|}{ Planting date (P.D) } \\
\hline 15 April & 191.77 & 219.73 & 5.90 & 9.50 \\
\hline 15 May & 196.33 & 201.11 & 7.93 & 10.23 \\
\hline \multicolumn{5}{|c|}{ C.V * P.D } \\
\hline \multicolumn{5}{|c|}{ Fusaeu } \\
\hline 15 April & 182.22 & 228.93 & 5.86 & 10.86 \\
\hline 15 May & 186.66 & 171.33 & 7.60 & 9.93 \\
\hline \multicolumn{5}{|c|}{ Local } \\
\hline 15 April & 201.33 & 210.53 & 5.93 & 8.13 \\
\hline 15 May & 206.00 & 230.90 & 8.26 & 10.53 \\
\hline LSD AT $0.05 \%$ & 2007 & 2008 & 2007 & 2008 \\
\hline C.V & 3.31 & 1.13 & N.S & N.S \\
\hline P.D & 3.38 & 2.08 & N.S & N.S \\
\hline C.V * P.D & 4.78 & 2.93 & N.S & N.S \\
\hline
\end{tabular}

Regarding the effect of planting date, $15^{\text {th }}$ of May was increased significantly plant height in the first season whereas $15^{\text {th }}$ of April increased the stem height in the second season. The number of lateral branches was not affected by planting dates.

The interaction had significant effect on plant height, plants of Local cultivar planted April on $15^{\text {th }}$ of May the highest compared with other interactions in both seasons.

Results show also that no significant differences in number of main lateral branches per plant in treatments were tested in both seasons. These variations could be due to the genetically condition of the two cultivars under this study .Similar finding were reported by Soja et al.(1990).

Yield and its components.

Data in Table (2) clearly indicated that Local cultivar produced higher in total yield per fed-1. and in marketable yield, tuber weight per plant and average tuber weight in two seasons. However, the differences were only significant in the second for total yield and in the two seasons for tuber weight. Superiority could be attributed to the varietal differences between the two cultivars. This results was also reported by Hamed (2001) .Also, differences in productivity between the Local and Fusaeu cultivars could be explained based on the genetic differences of the two cultivars. Similar 
findings among Jerusalem artichoke cultivars and clones had been previously reported by Khereba (1979) and Spitters (1987). Results presented in Table (2) showed that planting dates did not significantly affect tuber yield and its components, i.e., total and marketable yield in ton per fed., total yield per plant and average tuber fresh weight in two seasons. These results may be due to that Jerusalem artichoke plants produced quickly vegetative growth under long day and high temperature but to the formation of producing tubers depends on a low temperature and short day harvest time (Arslan, 1985). Results revealed that the harvesting date $15^{\text {th }}$ Nov. increased total and marketable tubers yield in ton per fed, tuber yield per plant and average tuber fresh weight. In general compared with the harvesting date $15^{\text {th }}$ Dec. This might be due to environmental conditions at harvest time in $15^{\text {th }}$ Nov. such as temperature at day and night and short day all these factors stimulated increasing tubers yield. Similar conclusions were obtained by (Leible and Kahnt, (1988), Soja et.al ,(1990), and Saengthongpinit, and Sajjaanantakul ,(2005).

Table (2): Effect of cultivar, planting dates and harvesting dates on total yield and its components on Jerusalem artichoke tubers during 2007 and 2008 seasons.

\begin{tabular}{|l|c|c|c|c|c|c|c|c|}
\hline \multirow{2}{*}{ Treatments } & $\begin{array}{c}\text { Total yield(ton/ } \\
\text { fed ) }\end{array}$ & $\begin{array}{c}\text { Marketable yield(ton } \\
\text { / fed ) }\end{array}$ & $\begin{array}{c}\text { Tuber fresh Weight } \\
\text { (gm) }\end{array}$ & $\begin{array}{c}\text { Tuber yield / plant } \\
\text { (kg) }\end{array}$ \\
\cline { 2 - 9 } & 2007 & 2008 & 2007 & 2008 & 2007 & 2008 & 2007 & 2008 \\
\hline \multicolumn{7}{|c|}{ Cultivars (C.V) } \\
\hline Fusaeu & 20.30 & 16.42 & 15.41 & 14.67 & 41.10 & 39.22 & 3.62 & 3.49 \\
\hline Local & 21.50 & 19.31 & 15.62 & 14.80 & 46.22 & 43.93 & 3.99 & 3.86 \\
\hline \multicolumn{8}{|c|}{ Planting dates (P.D) } \\
\hline 15 April & 21.41 & 18.45 & 16.07 & 15.07 & 46.03 & 43.79 & 3.62 & 3.49 \\
\hline 15 May & 20.39 & 17.28 & 14.96 & 16.40 & 41.29 & 39.36 & 3.99 & 3.86 \\
\hline \multicolumn{8}{|c|}{ Harvesting dates (H.D) } \\
\hline $15 / 11$ & 23.49 & 18.43 & 17.78 & 15.70 & 46.60 & 45.41 & 4.21 & 3.19 \\
\hline $15 / 12$ & 18.31 & 17.09 & 13.25 & 15.76 & 39.72 & 37.74 & 3.39 & 3.61 \\
\hline LSD at 0.05 \% & 2007 & 2008 & 2007 & 2008 & 2007 & 2008 & 2007 & 2008 \\
\hline C.V & N.S & 0.92 & N.S & N.S & 4.60 & 4.45 & N.S & N.S \\
\hline P.D & N.S & N.S & N.S & N.S & N.S & N.S & N.S & N.S \\
\hline H.D & 2.58 & N.S & 1.16 & N.S & 7.11 & 7.37 & 0.72 & N.S \\
\hline
\end{tabular}

Regarding the interactions between cultivars and planting dates, data in Table (3) show that the maximum values of total yield and marketable yield in ton per fed ${ }^{-1}$ were always recorded by planting on $15^{\text {th }}$ April with Local cultivar in both seasons. While ,the interaction between Local cultivar and planting date $15^{\text {th }} \mathrm{April}$ had no significant effect on total tubers yield per plant in two seasons, and average tuber fresh weight in first season only. This could be due to the relationship between the vegetative growth .specially plant height of plant and yield parameters .Similar opinion were reported by EL-Banna and Haggag (2005). 
Table (3): Effect of interactions between cultivars * planting dates, cultivars* harvesting dates and planting dates * harvesting dates on its components during 2007 and 2008 season.

\begin{tabular}{|c|c|c|c|c|c|c|c|c|}
\hline \multirow[t]{2}{*}{ Treatments } & \multicolumn{2}{|c|}{$\begin{array}{l}\text { Total yield } \\
\text { (ton / fed) }\end{array}$} & \multicolumn{2}{|c|}{$\begin{array}{c}\text { Marketable yield } \\
\text { (ton / fed) }\end{array}$} & \multicolumn{2}{|c|}{$\begin{array}{l}\text { Tuber fresh } \\
\text { weight(gm) }\end{array}$} & \multicolumn{2}{|c|}{$\begin{array}{c}\text { Tuber yield / plant } \\
\text { (kg) }\end{array}$} \\
\hline & 2007 & 2008 & 2007 & 2008 & 2007 & 2008 & 2007 & 2008 \\
\hline \multicolumn{9}{|c|}{ C.V ${ }^{*}$ P.D } \\
\hline \multicolumn{9}{|l|}{ Fusaeu } \\
\hline 15 April & 21.08 & 17.54 & 16.00 & 13.79 & 42.57 & 40.49 & 3.62 & 3.45 \\
\hline 15 May & 19.51 & 15.29 & 14.82 & 15.55 & 39.63 & 37.95 & 3.67 & 3.54 \\
\hline \multicolumn{9}{|l|}{ Local } \\
\hline 15 April & 21.74 & 19.29 & 16.15 & 16.15 & 49.50 & 47.65 & 3.61 & 3.53 \\
\hline 15 May & 21.27 & 19.27 & 15.10 & 17.25 & 42.95 & 40.21 & 4.30 & 4.19 \\
\hline \multicolumn{9}{|c|}{ C.V*H.D } \\
\hline \multicolumn{9}{|l|}{ Fusaeu } \\
\hline 15 Nov. & 22.92 & 15.81 & 17.19 & 14.04 & 45.03 & 43.16 & 4.26 & 3.42 \\
\hline 15 Dec. & 17.69 & 17.02 & 13.63 & 13.63 & 37.18 & 35.28 & 3.04 & 3.57 \\
\hline \multicolumn{9}{|l|}{ Local } \\
\hline 15 Nov. & 24.07 & 21.46 & 18.38 & 17.37 & 50.18 & 47.10 & 4.17 & 3.81 \\
\hline 15 Dec. & 18.95 & 17.17 & 12.87 & 16.23 & 42.27 & 40.21 & 3.74 & 3.90 \\
\hline \multicolumn{9}{|c|}{ P.D* H.D } \\
\hline \multicolumn{9}{|l|}{15 April } \\
\hline 15 Nov. & 24.55 & 18.91 & 18.41 & 15.28 & 50.28 & 47.71 & 4.07 & 3.55 \\
\hline 15 Dec. & 18.28 & 17.99 & 13.74 & 14.86 & 41.79 & 39.88 & 3.16 & 3.43 \\
\hline \multicolumn{9}{|l|}{15 May } \\
\hline 15 Nov. & 22.43 & 18.26 & 17.16 & 16.13 & 44.93 & 43.10 & 4.36 & 3.68 \\
\hline 15 Dec. & 18.36 & 16.20 & 12.76 & 16.66 & 37.65 & 35.61 & 3.62 & 4.05 \\
\hline LSD at $0.05 \%$ & 2007 & 2008 & 2007 & 2008 & 2007 & 2008 & 2007 & 2008 \\
\hline C.V* P.D & 2.22 & 2.00 & N.S & 3.12 & N.S & N.S & N.S & 0.70 \\
\hline C.V ${ }^{*}$ H.D & 2.59 & 1.08 & 1.65 & 2.04 & 10.06 & 10.42 & 1.02 & N.S \\
\hline P.D*H.D & 2.59 & 2.00 & 1.65 & N.S & 10.06 & 10.42 & 1.02 & N.S \\
\hline
\end{tabular}

Results presented in Table (3) also, reported that the interactions between cultivars and harvesting dates were significant effects. Therefore, Local cultivar plant harvested on $15 \mathrm{Nov}$.produced high total tuber yield, marketable yield ,tuber fresh weight and total yield per plant in both seasons. These results are in harmony with those obtained by Baldini et al. (2004) and, Soja et al. (1990), and Saengthongpinit, and Sajjaanantakul , (2005).

The interactions between planting dates and harvesting dates in Table (3) had also significant effect on total tubers yield and its components .Data showed that planting date $15^{\text {th }}$ April with harvesting date $15^{\text {th }}$ Nov. significantly increased total yield and marketable yield. Results also indicated that planting date $15^{\text {th }}$ April with harvesting date $15^{\text {th }} \mathrm{Nov}$. increased tuber fresh weight during two seasons.

Concerning the effect of the interactions between cultivars and planting dates with harvesting dates in Table (4), data show that Local cultivar planted on $15^{\text {th }}$ April and harvested on $15^{\text {th }}$ Nov. produced a highly significant increase in total yield, marketable yield and average tuber weight compared with other treatments under this study in two seasons. Similar results were 
obtained on total yield per plant in second season. These results due to that the cultivars had different response patterns at different times of planting and harvesting of the year Baldini et al. (2004).

Table (4): Effect of interactions between cultivars, planting dates and harvesting dates on yield and its component during 2007 and 2008 seasons.

\begin{tabular}{|c|c|c|c|c|c|c|c|c|c|c|}
\hline \multicolumn{3}{|c|}{ Treatments } & \multicolumn{2}{|c|}{$\begin{array}{l}\text { Total yield } \\
\text { (ton / fed) }\end{array}$} & \multicolumn{2}{|c|}{$\begin{array}{c}\text { Marketable } \\
\text { yield } \\
\text { (ton / fed) }\end{array}$} & \multicolumn{2}{|c|}{\begin{tabular}{|c|}
$\begin{array}{c}\text { Tuber } \\
\text { fresh } \\
\text { weight(gm) }\end{array}$ \\
\end{tabular}} & \multicolumn{2}{|c|}{$\begin{array}{c}\text { Tuber yield / } \\
\text { plant } \\
(\mathbf{k g})\end{array}$} \\
\hline Cultivars & $\begin{array}{l}\text { Planting } \\
\text { dates }\end{array}$ & $\begin{array}{l}\text { Harvesting } \\
\text { dates }\end{array}$ & 2007 & 2008 & 2007 & 2008 & 2007 & 2008 & 2007 & 2008 \\
\hline \multirow[t]{4}{*}{ Fusaeu } & \multirow[t]{2}{*}{15 April } & $15 / 11$ & 24.23 & 17.37 & 17.48 & 13.18 & 44.37 & 42.06 & 4.20 & 3.45 \\
\hline & & $15 / 12$ & 17.94 & 17.71 & 14.52 & 14.40 & 40.78 & 38.91 & 3.04 & 3.45 \\
\hline & \multirow{2}{*}{15 May } & $15 / 11$ & 21.59 & 14.26 & 16.89 & 14.90 & 45.60 & 44.26 & 4.31 & 3.39 \\
\hline & & $15 / 12$ & 17.43 & 16.33 & 12.75 & 16.20 & 33.58 & 31.65 & 3.04 & 3.69 \\
\hline \multirow{4}{*}{ Local } & \multirow{2}{*}{15 April } & $15 / 11$ & 24.87 & 20.47 & 19.33 & 17.38 & 56.19 & 53.36 & 3.94 & 3.69 \\
\hline & & $15 / 12$ & 18.62 & 18.26 & 12.97 & 15.33 & 42.81 & 40.84 & 3.29 & 3.40 \\
\hline & \multirow{2}{*}{15 May } & $15 / 11$ & 23.26 & 22.47 & 17.44 & 17.13 & 44.18 & 41.95 & 4.40 & 3.97 \\
\hline & & $15 / 12$ & 19.28 & 16.07 & 12.76 & 17.13 & 41.72 & 39.58 & 4.20 & 4.40 \\
\hline \multicolumn{3}{|c|}{ LSD at $0.05 \%$} & 2007 & 2008 & 2007 & 2008 & 2007 & 2008 & 2007 & 2008 \\
\hline \multicolumn{3}{|c|}{$\begin{array}{l}\text { Cultivars X Planting dates } X \\
\text { Harvesting dates }\end{array}$} & 3.66 & 2.79 & 2.33 & 2.89 & 14.22 & 14.74 & N.S & 0.96 \\
\hline
\end{tabular}

\section{Dry matter, Inulin and total sugar of tubers.}

Local cultivar produced tubers with significantly higher content of dry matter; inulin and total sugar than Fusaeu, in both years, Table (5).Dry matter of Local cultivar were 22.44 and $24.21 \%$ in comparison to 22.15 and $23.65 \%$ for the Fusaeu .during two seasons, respectively. Inulin of Local cultivar was 10.03 , and $8.90 \%$ in comparison to 9.43 , and $8.64 \%$ for Fusaeu in both seasons. Regarding the content of total sugar increased 8.34 , and $8.86 \%$ in Local cultivar to 8.03 , and $8.59 \%$ for Fusaeu in two seasons, respectively. Differences in tuber DM, inulin and total sugar might be due to genetic differences among Jerusalem artichoke cultivars (Baldini et al.,2004).Opposite results were indicated by Tawfik et al .(2003). This could be related to the differences in the prevailing environmental conditions at the each study.

The higher contents of dry matter, total sugars in tubers Jerusalem artichoke were recorded at planting date of $15^{\text {th } A p r i l ~(T a b l e ~ 5) . ~ T h i s ~}$ superiority might be due to the favorable effects of high temperature and long day during the periods, which simulate the plant metabolism and increase the vegetative growth of the plant and consequently more metabolites are stored in tubers. Similar conclusions were obtained by EL- Banna and Haggag (2005). 
Table (5): Effect of cultivars, planting dates and harvesting dates on dry matter ,inulin and total sugars percentage in tubers during 2007 and 2008 seasons.

\begin{tabular}{|l|c|c|c|c|c|c|}
\hline \multirow{2}{*}{ treatments } & \multicolumn{2}{|c|}{$\begin{array}{c}\text { Dry matter } \\
\text { (D.W) }\end{array}$} & \multicolumn{2}{c|}{$\begin{array}{c}\text { Iulin } \\
\text { (D.W) }\end{array}$} & \multicolumn{2}{c|}{$\begin{array}{c}\text { Total sugars } \\
\text { (F.W) }\end{array}$} \\
\cline { 2 - 7 } & 2007 & 2008 & 2007 & 2008 & 2007 & 2008 \\
\hline Cultivars & & & & & & \\
\hline Local & 22.44 & 24.21 & 10.03 & 8.90 & 8.34 & 8.86 \\
\hline Fusaeu & 22.15 & 23.65 & 9.43 & 8.64 & 8.03 & 8.59 \\
\hline Planting dates & & & & & & \\
\hline $15 / 4$ & 22.88 & 24.51 & 9.91 & 8.97 & 8.35 & 8.84 \\
\hline $15 / 5$ & 21.71 & 23.35 & 9.05 & 8.57 & 8.02 & 8.62 \\
\hline Harvesting dates & & & & & & \\
\hline $15 / 11$ & 22.98 & 24.68 & 10.09 & 9.29 & 8.02 & 8.59 \\
\hline $15 / 12$ & 21.61 & 23.18 & 9.21 & 8.25 & 8.34 & 8.86 \\
\hline LSD at $0.05 \%$ & & & & & & \\
\hline Cultivars & 0.11 & 0.12 & 0.19 & 0.10 & 0.12 & 0.09 \\
\hline Planting dates & 0.13 & 0.15 & 0.20 & 0.12 & 0.13 & 0.10 \\
\hline Harvesting dates & 0.22 & 0.19 & 0.21 & 0.13 & 0.08 & 0.10 \\
\hline
\end{tabular}

Regarding harvesting dates, it was found that the percentage of dry matter, inulin in tubers were significantly increased while total sugars decreased when harvested on $15^{\text {th }}$ Nov.Compared with tubers harvested on $15^{\text {th }}$ Dec. This result is in the same trend with Galindo and Guiraud, (1997) and Saengthongpinit and Sajjaanantakul,(2005).They reported that chemical constituents in tubers were affected by climate changes during harvest period which increasing storage roots total carbohydrate in early harvest .

The interactions in Table (6) between cultivars and planting dates had significant effect on the tubers contents of dry matter, inulin and total sugar in two seasons. Local cultivar plants planted on $15^{\text {th }}$ April showed higher contents of dry matter, inulin and total sugar compared with other treatments in both seasons.

Data presented in Table (6), explained that the interactions between cultivars and harvesting dates also had significant increases in tuber contents of dry matter, inulin and total sugar .Local cultivar tubers harvested on $15^{\text {th }}$ Nov. showed higher contents of dry matter, inuln and total sugar than those Fusaeu harvested on $15^{\text {th }}$ Dec. and during two seasons. The positive effects of Local cultivar (at harvesting date $15^{\text {th }}$ Nov. ) on increasing tuber carbohydrate could be due to allowing more carbohydrate synthesis and translocation of the assimilates from the vegetative growth to tubers (Soja et al ,1990). Differences of tuber dry matter, inulin and total sugar among Jerusalem artichoke cultivars were reported by Zubr et al ,(1993) ,Hamed ,(2001), Baldini et al( 2005 ).

Also, the interaction between planting dates and harvesting dates ( Table 6), indicated that planting date $15^{\text {th }}$ April with harvesting date $15^{\text {th }}$ Nov. recorded higher contents of dry matter, inulin and total sugar than those planted on $15^{\text {th }}$ May with harvest on $15^{\text {th }}$ Dec. Similar results were reported by Soja et al (1990), and Baldini et al (2005). 
Table (6): Effect of interactions between cultivars and planting dates (C.V*P.D), cultivars and harvesting dates (C.V*H.D) and planting dates, harvesting dates (P.D*H.D) on dry matter, inulin and total sugars percentage during 2007 and 2008 seasons.

\begin{tabular}{|c|c|c|c|c|c|c|}
\hline \multirow[t]{2}{*}{ Treatment } & \multicolumn{2}{|c|}{$\begin{array}{l}\text { Dry matter } \\
\text { (D.W) }\end{array}$} & \multicolumn{2}{|c|}{$\begin{array}{l}\text { Inulin } \\
\text { (D.W) }\end{array}$} & \multicolumn{2}{|c|}{$\begin{array}{l}\text { Total sugars } \\
\text { (F.W) }\end{array}$} \\
\hline & 2007 & 2008 & 2007 & 2008 & 2007 & 2008 \\
\hline \multicolumn{7}{|c|}{ C.V*P.D } \\
\hline Local $^{*} 15 / 4$ & 23.01 & 24.74 & 10.28 & 9.07 & 8.51 & 8.99 \\
\hline Local *15/5 & 21.87 & 23.68 & 9.78 & 8.73 & 8.17 & 8.73 \\
\hline Fusaeu ${ }^{\star} 15 / 4$ & 22.78 & 24.28 & 9.54 & 8.87 & 8.19 & 8.68 \\
\hline Fuseau ${ }^{*} 15 / 5$ & 21.55 & 23.00 & 9.31 & 8.41 & 7.87 & 8.51 \\
\hline \multicolumn{7}{|c|}{ C.V *H.D } \\
\hline Local *15/11 & 23.12 & 24.87 & 10.57 & 9.36 & 8.13 & 8.74 \\
\hline Local *15/12 & 21.76 & 23.54 & 9.48 & 8.42 & 8.54 & 8.97 \\
\hline Fusaeu ${ }^{*} 15 / 11$ & 23.34 & 24.48 & 9.92 & 9.20 & 7.91 & 8.43 \\
\hline Fusaeu ${ }^{\star} 15 / 12$ & 21.46 & 22.82 & 8.93 & 8.07 & 8.11 & 8.74 \\
\hline \multicolumn{7}{|c|}{ P.D * H.D } \\
\hline \multicolumn{7}{|l|}{15 April } \\
\hline $15 / 11$ & 23.55 & 25.33 & 10.42 & 9.44 & 8.12 & 8.69 \\
\hline $15 / 12$ & 22.21 & 23.68 & 9.40 & 8.49 & 8.57 & 8.97 \\
\hline \multicolumn{7}{|l|}{15 May } \\
\hline $15 / 11$ & 22.91 & 24.01 & 10.07 & 9.13 & 7.91 & 8.49 \\
\hline $15 / 12$ & 21.01 & 22.68 & 9.01 & 8.00 & 8.11 & 8.74 \\
\hline LSD at $0.05 \%$ & 2007 & 2008 & 2007 & 2008 & 2007 & 2008 \\
\hline C.V*P.D & 0.13 & 0.15 & 0.14 & 0.16 & 0.11 & 0.11 \\
\hline C. $V^{*} H D$ & 0.14 & 0.17 & 0.16 & 0.17 & 0.13 & 0.13 \\
\hline P.D*H.D & 0.16 & 0.18 & 0.18 & 0.18 & 0.13 & 0.13 \\
\hline
\end{tabular}

Concerning the effect of the interactions among cultivars, planting dates and harvesting dates on tuber contents of dry matter, inulin total sugar (Table 7). Local cultivar planted on $15^{\text {th }}$ April and harvested tubers on $15^{\text {th }}$ Nov. produced a significant increases on tubers contents of dry matter, inulin and total sugar compared with other factors under this study.

Table (7): Effect of interactions between cultivars, planting dates and harvesting dates on dry matter, inulin and total sugars percentage in tubers during 2007 and 2008 seasons.

\begin{tabular}{|l|c|c|c|c|c|c|}
\hline \multirow{2}{*}{ Treatment } & \multicolumn{2}{|c|}{$\begin{array}{c}\text { Dry matter } \\
\text { (D.W) }\end{array}$} & \multicolumn{2}{c|}{$\begin{array}{c}\text { Inulin } \\
\text { (D.W) }\end{array}$} & \multicolumn{2}{c|}{$\begin{array}{c}\text { Total sugars } \\
\text { (F.W) }\end{array}$} \\
\cline { 2 - 7 } & 2007 & 2008 & 2007 & 2008 & 2007 & 2008 \\
\hline Local & & & & & & \\
\hline 15 April & & & & & & 8.85 \\
\hline $15 / 11$ & 23.65 & 25.53 & 10.82 & 9.48 & 8.24 & 9.12 \\
\hline $15 / 12$ & 22.37 & 23.95 & 9.74 & 8.65 & 8.78 & \\
\hline 15 May & & & & & & 8.64 \\
\hline $15 / 11$ & 22.58 & 24.21 & 10.32 & 9.25 & 8.02 & 8.82 \\
\hline $15 / 12$ & 21.15 & 23.14 & 9.23 & 8.20 & 8.31 & \\
\hline Fusaeu & & & & & & \\
\hline 15 April & & & & & & 8.53 \\
\hline $15 / 11$ & 23.44 & 25.14 & 10.03 & 8.90 & 8.34 & 8.82 \\
\hline $15 / 12$ & 22.75 & 23.42 & 10.02 & 9.40 & 8.01 & \\
\hline 15 May & & & & & & 8.34 \\
\hline $15 / 11$ & 23.23 & 23.82 & 9.82 & 9.01 & 7.81 & 8.67 \\
\hline $15 / 12$ & 20.86 & 22.22 & 8.80 & 7.81 & 7.92 & 8.12 \\
\hline LSD at 0.05\% & 2007 & 2008 & 2007 & 2008 & 2007 & 2008 \\
\hline C.V*P.D*H.D & 0.18 & 0.19 & 0.19 & 0.21 & 0.15 & 0.14 \\
\hline
\end{tabular}




\section{REFERENCES}

AOAC (1980). Official Methods of Analysis $.13^{\text {th }}$ Ed. Association of Official Chemists Washington DC. USA.

Arslan, N., (1985.) Influence of planting time on the tuber and herbage yield of (Helianthus tuberoses L.) Doga -Bilim - Deryisi, D2 Tarm-VeOrmanck, 1985,912: 183-187.

Baldini ,M. Danuso,F.Turi, and M. Vannozzi,G.p.(2004). Evaluation of clones of Jerusalem artichoke (Helianthus tuberosus $L$ ) for inulin and sugar yield from stalks and tubers. Industrial Crop and Products 19: 2540.

Chubey, B. B and D G. Dorrell (1974).Jerusalem artichoke, potential fructose crop forth prairies. Canadian Inst .Food Science and Tech. 7(2):98100.

D"egidio, M .G.,C ., Cervingi, T.Donini.B. and, V.Pignatelli,,(1998). Production of fructose from cereal stems and polyannual cultures of Jerusalem artichoke. Ind.Crops Prod.7: 113-119.

EL-Banna, E.N.and A. A. Haggag (2005).Study effect of sprouting seed and planting dates on growth and yield of Taro plant (Colocasia esculanta L.) at North Delta Region. J. Agric. Sci. Mansoura Uni., 30 (12) : 78957906.

Galindo,S ., S and ,J.P.,Guiraud (1997). Sugar potential of different Jerusalem artichoke cultivars according to harvest. Bioresource Technology 60: 15-20.

Hamed ,N.M. (2001). Effect of cultivar and location on yield tuber quality and storability of Jerusalem artichoke .M.Sc. Thesis, Faculty of Agriculture, Ain Shams University ,Egypt.

Khereba, A. H. A.(1979).New Clones of Jerusalem artichoke. (Helianthus tuberosus L.) Research Bull. No. Faculty of Agriculture, Ain Shams University, Egypt

Klaushofer, H., (1986). Zur Biotechnological fructosanhaltiger Pflanzen. Starch 38: 91-94.

Leible, L. and Kahnt,G.(1988).Effect of location, N-Fertilization, cultivar and harvest date on the yield of fermentable sugar of Jerusalem artichoke tops and tubers. Journal of Agronomy and crop Science,1988, 161(5):339-352.

Nelson,N,(1974).A photometric adaptation of The Somogyi methods for determination of glucose .J.Biology.Chem.195:19-23.

Paolini,R., Del Puglia, S..,Abbate,V., Copani, V., Danuso,F., De Mastro,G.,Losavio.N., Marzi, V.,Molfetta,P., Pignatelli,V.,Venezia,G., and Vonella,A. V.(1996).Porduttivita del topinambur (Helianthus tuberosus $\mathrm{L}$,) in relzione a fattori agronomici diversi. Agric.Ricerca XVIII 163,126-144. 
SAS Institute, I. (1989).User, s Guide version 6 .(4th Ed), Cary, N.Carolina, SAS Institue , Inc., 846 pp.

Saengthongpinit,W., And Sajjaanantakul, T., (2005). Influence of harvest time and storage temperature on characteristics of inulin from Jerusalem artichoke (Helianthus tuberous L.) tubers. Postharvest Biology and Technology 37: 93-100.

Somogyi,M (1952).Notes on sugar determination .J. Biology Chem. 195:1923.

Soja, G., G., G., Dersch and W. Praznik. (1990).Harvest dates, fertilizer and varietal effects on yield, concentration and molecular distribution of fructan in Jerusalem artichoke (Helianthus tuberous L.). Journal of Agronomy and crop Science 165: 181-189.

Spitters , G. J. (1987).Jerusalem artichoke, a new crop for the sweetener market. Prophyta, 41:259-261.

Tawfik ,A. A. ,Bekhit,R. S. ,Emara ,M.R.Kereba , A.H.,and EL-Sharkawy (2003). Effect of cultivar and potassium fertilization rate on total yield, chemical constituents and storability of Jerusalem artichoke tubers. J. Agr. Sci. Mansoura Uni. , 28(1):493-512.

Zubr, J., Pedersen, H.S., (1993).Characteristis of growth and development of different Jerusalem artichoke cultivars. In: Fuchs $A$.(Ed.), Inulin and Inulun - Containing Crops, Elsevier, Amsterdam, pp 11-19.

Winton. A.L. and K.B. Winton( 1958).The analysis of foods. John Wiley and Sons. Inc .London. 857.

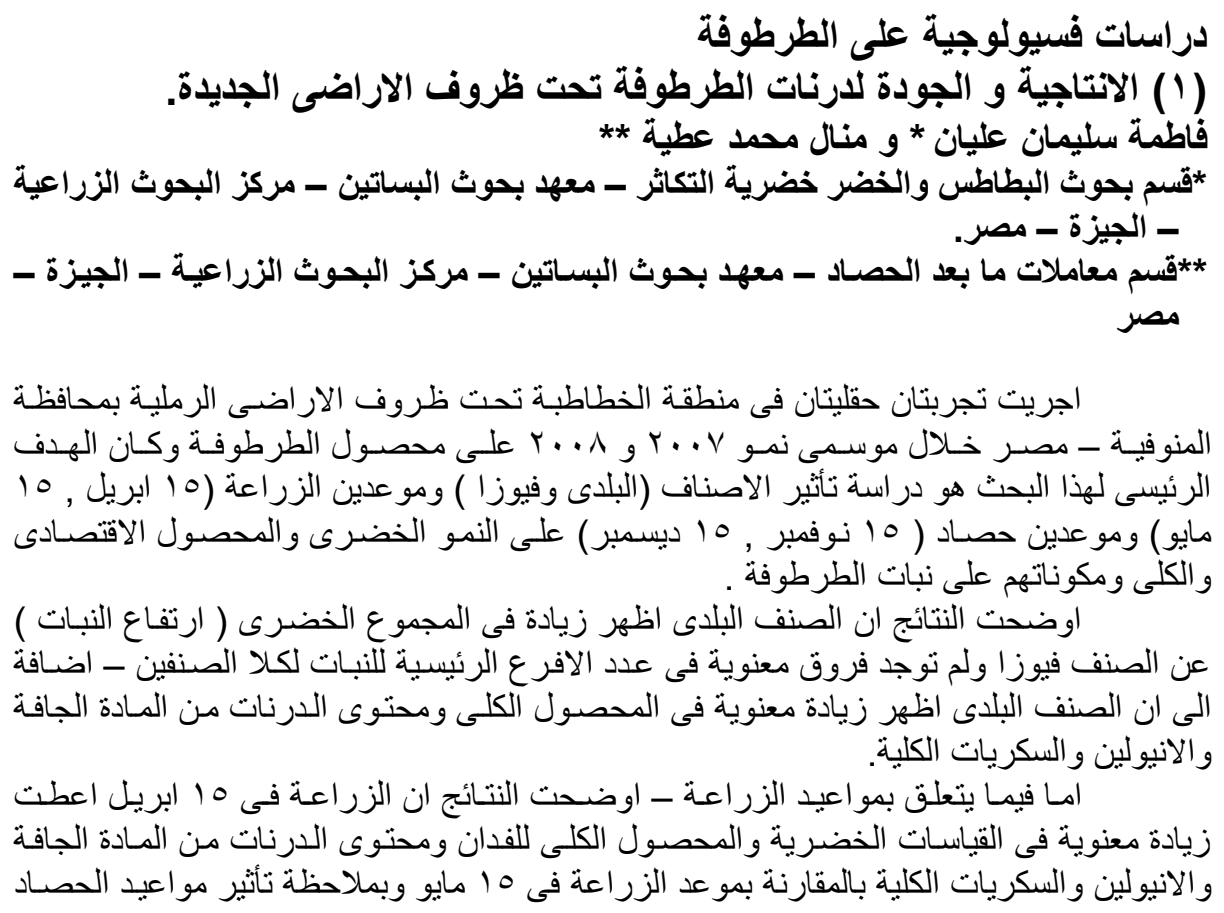




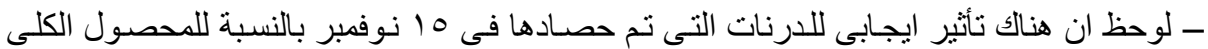

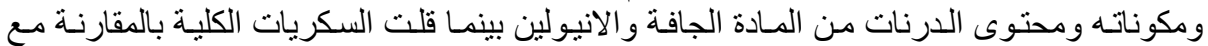

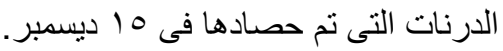

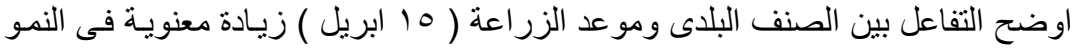

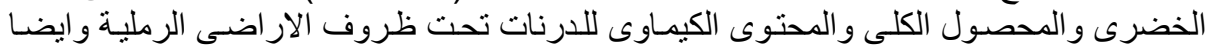

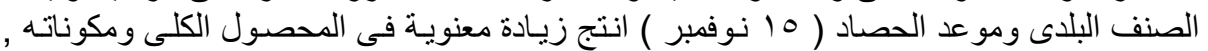

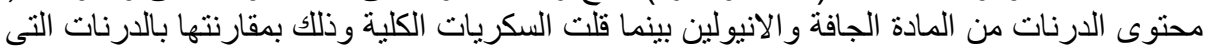

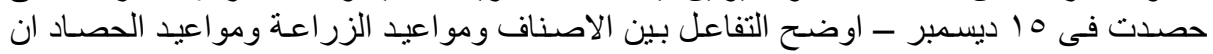

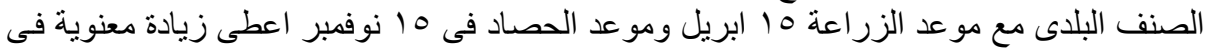

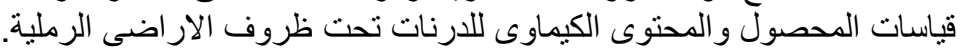

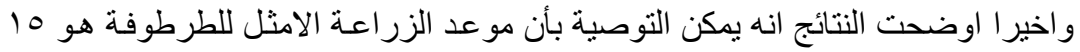

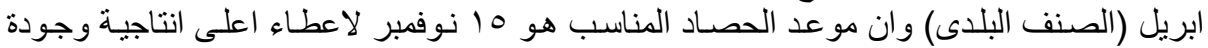
للارنات فى الار اضى الرملية.

كلية الزراعة - جامعة المنصورة

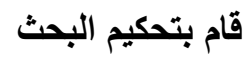
كلية الزراعة - جامعة عين شمس أ.د / سمير طه العفيفى أ.د / ابراهيم ابراهيم العكش 
Alian, Fatma S. and Manal M. Attia

1711 